\title{
Gender differentials in the health status of geriatric age group and their coping mechanisms
}

\author{
S. Priyanka ${ }^{1}$, Christina Mary P. Paul ${ }^{1}$, Daisy Dharmaraj ${ }^{1}$, K. K. Dutta Gupta ${ }^{1}$, \\ P. A. Archanalakshmi ${ }^{2}$, Veena Paul V. S. ${ }^{3}$
}

\begin{abstract}
${ }^{1}$ Department of Community Medicine, ACS Medical College, Chennai, Tamil Nadu, India
${ }^{2}$ Department of Community Medicine, Karpaga Vinayaga Medical College, Chennai, Tamil Nadu, India

${ }^{3}$ Department of Pathology, ACS Medical College, Chennai, Tamil Nadu, India
\end{abstract}

Received: 07 September 2016

Revised: 09 September 2016

Accepted: 12 September 2016

\author{
*Correspondence: \\ Dr. Christina Mary P. Paul, \\ E-mail: christinapaul82@gmail.com
}

Copyright: (c) the author(s), publisher and licensee Medip Academy. This is an open-access article distributed under the terms of the Creative Commons Attribution Non-Commercial License, which permits unrestricted non-commercial use, distribution, and reproduction in any medium, provided the original work is properly cited.

\begin{abstract}
Background: The present study was conducted to estimate the gender differentials in health problems and access to health care in the geriatric population and to study the social and economic mechanisms they have to cope.

Methods: This study was done as a cross-sectional study with both analytical and descriptive components in Parivakkam and Kolappancheri villages of Thiruvallur district. Simple random sampling was used to identify 110 men and 110 women in the geriatric age group. Data was collected through a tailor-made interview schedule after reviewing questionnaires used for the geriatric population. Data entry was done in SPSS version-15. Chi-square values were calculated wherever appropriate and $\mathrm{p}$-values were based on the 2-tailed values.

Results: A significant difference was found between educational qualifications and gender ( $\mathrm{p}$-value $=0.000 *$ ), and men had higher per-capita income than women with a statistically significant association ( $\mathrm{p}$-value $=0.04)$. Self-earning as the main source of income was seen in $46 \%$ of the men and was more than that for women (22\%). There were statistically significant differences in the main source of income between males and females ( $\mathrm{p}$-value $=0.003 *)$. It was seen that more women were on irregular treatment $(\mathrm{p}$-value $=0.002)$. Utilization of health care services was better among women than men.

Conclusions: High prevalence of morbidities and health complaints and the poor health seeking behaviour of the elderly emphasize on the need for health programs for the elderly.
\end{abstract}

Keywords: Gender, Geriatric, Rural, Morbidities

\section{INTRODUCTION}

The UN defines a country as 'ageing' when the proportion of people over 60 reaches 7 percent. In India, currently $7.8 \%$ of the populations are elderly and it is expected that this will reach $12.6 \%$ in $2025 .{ }^{1}$ Expectation of life at birth for males and females by 2011-2016 has been projected to be 67 and 69 years respectively. ${ }^{2}$ The Government of India adopted 'National Policy on Older
Persons' in January, 1999. The policy defines 'senior citizen' or 'elderly' as a person who is of age 60 years or above. $^{3}$

The health of older people has sometimes been treated as less important than that of younger people, either because older people are considered less productive or because illhealth is deemed an inevitable consequence of later life. Furthermore, older people are often regarded as a 
homogenous group which in turn conceals inequalities in this population. ${ }^{4}$ According to recent statistics related to elderly people in India, in the year 2001, it was observed that as many as $75 \%$ of elderly persons were living in rural areas. About $48.2 \%$ of elderly persons were women, out of whom $55 \%$ were widows. ${ }^{5}$

In India, the elderly suffer from dual medical problems, i.e., both communicable as well as non-communicable diseases. This is further compounded by impairment of special sensory functions like vision and hearing. A decline in immunity as well as age related physiologic changes leads to an increased burden of communicable diseases in the elderly. ${ }^{5}$

According to a study done among the elderly in Shimla, the problems faced by females are more critical compared to that of males due to low literacy rate, customary ownership of property by men, and majority of women not having been employed during their prime age and with only very few having been in the organized sector. 6 The mean numbers of morbidities were significantly higher among females as compared with males, and the reasons quoted for the same were that older women were more likely than older men to be unemployed, and/or widowed, and to engage in less exercise. ${ }^{7}$

Hence a study was taken up with the objectives of estimating the health problems of women and men in geriatric population and the gender differentials in access to health care and to study the social and economic mechanisms they have to cope with their situation and also to suggest changes needed to help them to overcome the gender differentials and gaps in health care services.

\section{METHODS}

\section{Study design}

This study was done as a cross-sectional study with both analytical and descriptive components. The descriptive component was used to estimate the prevalence of health problems among the geriatric population. The analytical component was used to find the association between gender and certain factors suspected to have a bearing on the health status of the geriatric population.

\section{Study setting and subjects}

The study was conducted from June 2013 to August 2013 in Parivakkam and Kolappancheri villages of Thiruvallur district, which are the field practice areas of A.C.S Medical College.

\section{Selection and distribution of participants}

Stratified random sampling method was used to identify 110 families with geriatric men and 110 families with geriatric women in the geriatric age group from Parivakkam and Kolappancheri villages, allowing a non- response rate of $10 \%$. The final non-response rate was $7 \%$ for women and $4 \%$ for men. The desired sample size of 200 which included 100 men and 100 women was achieved. Subjects were included in the study only after obtaining the informed consent. The study subjects were thanked for their co-operation for the study at the end of the study.

\section{Sample size and sampling unit}

A study done among the elderly population in Shimla showed that more women $(88 \%)$ than men $(80 \%)$ had at least one morbidity. ${ }^{7}$ Setting the prevalence at $80 \%$ and with an allowable error of $7 \%$ of prevalence (5.6), the minimum sample size was calculated to be 196 and it was decided to study a sample of 200.

\section{Ethical considerations}

Informed consent was translated into the regional language (Tamil) and a written informed consent was obtained from all the participants after explaining the purpose of this research. Institutional ethics committee approval was obtained from ACS Medical College.

\section{Definition and classification of main study variable}

\section{Education}

Based on the educational status the subjects were classified into four groups namely illiterates, primary school completers, secondary school completers and graduates and above.

\section{Socio-economic status}

The subjects were divided into five classes based on their per-capita income in accordance with the B.G Prasad 2013 revised classification of socio-economic status. ${ }^{8}$

\section{Morbidities and health complaints}

Diagnosis of a case of a particular morbidity or health complaint was based on the individual's information on that morbidity or health complaint and their perception of the same.

\section{Data analysis}

Information was collected from the participant using the pre-tested interview schedule. The data entry and analysis were done using statistical package for social sciences (SPSS) version 15. The final data was summarized into percentages and analyzed by cross tabulations for various variables. Chi-square values were calculated wherever appropriate and $\mathrm{p}$ values were based on the 2-tailed values. Associations were assessed through odds ratio and $95 \%$ confidence interval of the odds ratio which was found using Epi Info version 7.1.2. 


\section{RESULTS}

A population based cross-sectional study was undertaken to estimate the health problems in the geriatric population (> 60 years of age) and to identify the gender differentials in access to health care and the following observations were made.

\section{Socio-demographic profile}

The older ages were more common among the male population, the $80-89$ years age group had $6.5 \%$ of the total population of which was made of $3 \%$ females and $10 \%$ males. Highest number of men $(46 \%)$ said that selfearning was the main source of their income and among women the most common source of income was through relatives $(42 \%)$, there were statistically significant differences in the main source of income between males and females $(p=0.003 *)$. It was seen that literacy was more among the male population than in the female population in this study. $58 \%$ of the females and $29 \%$ of the males were illiterates in this study and there was a significant difference between educational qualifications and gender $\left(\mathrm{p}\right.$ value $\left.=0.000^{*}\right)$. There were more males when compared to females in the upper classes of B.G. Prasad classification (Class 1,2,3) and more females when compared to males in the lower classes (Class 4 and 5), there was a statistically significant difference gender and socio-economic status in the geriatric population $(\mathrm{p}=0.04 *)($ Table 1$)$.

Table 1: Gender differentials in certain socio-demographic profile of the geriatric subjects.

\begin{tabular}{|c|c|c|c|c|}
\hline $\begin{array}{l}\text { Variable } \\
\text { (Classification of the } \\
\text { variable) }\end{array}$ & $\begin{array}{l}\text { Numbers of females } \\
\text { (out of } 100 \text { hence is } \\
\text { a percentage also) }\end{array}$ & $\begin{array}{l}\text { Numbers of males } \\
\text { (out of } 100 \text { hence is } \\
\text { a percentage also) }\end{array}$ & $\begin{array}{l}\text { P-value } \\
\text { (based on chi- } \\
\text { square values) }\end{array}$ & $\begin{array}{l}\text { Total } \\
\text { Number (percentage } \\
\text { of total subjects) }\end{array}$ \\
\hline Age & & & \multirow{5}{*}{0.051} & \\
\hline $60-69$ & 67 & 64 & & $131(65.5)$ \\
\hline $70-79$ & 30 & 23 & & $53(26.5)$ \\
\hline $80-89$ & 3 & 10 & & $13(6.5)$ \\
\hline$>90$ & 0 & 3 & & $3(1.5)$ \\
\hline \multicolumn{5}{|l|}{ Religion } \\
\hline Hindu & 92 & 91 & \multirow{3}{*}{0.27} & $183(91.5)$ \\
\hline Muslim & 5 & 2 & & $7(3.5)$ \\
\hline Christian & 3 & 5 & & $8(4)$ \\
\hline \multicolumn{5}{|l|}{$\begin{array}{l}\text { Main source of } \\
\text { income }\end{array}$} \\
\hline Self- earning & 22 & 46 & \multirow{4}{*}{$0.003^{*}$} & $68(34)$ \\
\hline Through relatives & 42 & 29 & & $71(35.5)$ \\
\hline Pension & 34 & 25 & & $59(29.5)$ \\
\hline No income & 2 & 0 & & $2(1)$ \\
\hline \multicolumn{5}{|l|}{ Educational status } \\
\hline Illiterate & 58 & 29 & \multirow{4}{*}{$0.000 *$} & $87(43.5)$ \\
\hline Primary school & 35 & 48 & & $83(41.5)$ \\
\hline Secondary school & 7 & 20 & & $27(13.5)$ \\
\hline Graduate and above & 0 & 3 & & $3(1.5)$ \\
\hline \multicolumn{5}{|l|}{$\begin{array}{l}\text { S.E status based on } \\
\text { BG Prasad } \\
\text { classification }\end{array}$} \\
\hline Class I & 2 & 5 & \multirow{5}{*}{$0.04 *$} & $7(3.5)$ \\
\hline Class II & 11 & 13 & & $24(12)$ \\
\hline Class III & 9 & 21 & & $30(15)$ \\
\hline Class IV & 48 & 44 & & $92(46)$ \\
\hline Class V & 30 & 17 & & $47(23.5)$ \\
\hline
\end{tabular}

*statistically significant

\section{Details on known chronic diseases in the geriatric population}

Hypertension, physical disabilities, psychological problems and hearing/speech/visual problems were more common among females when compared to males. Complaints of diabetes, bronchial asthma and cardiac problems were more among males (Table 2).

\section{Association between 3 month recall of health problems and utilization of health services and gender in the geriatric population}

Complaints of loss of weight, loss of appetite and mobility problems were more common among females when compared to males and these associations were statistically significant with $\mathrm{p}$ values of $0.04,0.02$ and 0.0008 respectively. Parameters on utilization of health 
care services like hospital admissions, seeking specialist care and private facilities were significantly more among females with $\mathrm{p}$ values of $0.04,0.0008$ and 0.02 respectively (Table 3).

Table 2: Gender-wise distribution of known diseases in the geriatric subjects.

\begin{tabular}{|llll|}
\hline Nature of disease & $\begin{array}{l}\text { No of } \\
\text { females }\end{array}$ & $\begin{array}{l}\text { No of } \\
\text { males }\end{array}$ & $\begin{array}{l}\text { Total } \\
\text { (percentage) }\end{array}$ \\
\hline Hypertension & 62 & 55 & $117(58.5 \%)$ \\
\hline Diabetes & 26 & 33 & $59(29.5 \%)$ \\
\hline Bronchial asthma & 7 & 10 & $17(8.5 \%)$ \\
\hline Cardiac problems & 5 & 9 & $14(7 \%)$ \\
\hline Physical disabilities & 9 & 3 & $12(6 \%)$ \\
\hline $\begin{array}{l}\text { Psychological } \\
\text { problems }\end{array}$ & 2 & 1 & $3(1.5 \%)$ \\
\hline $\begin{array}{l}\text { Vision/speech/hearing } \\
\text { problems }\end{array}$ & 29 & 19 & $48(24 \%)$ \\
\hline
\end{tabular}

\section{Gender differentials in the regularity of treatment in the geriatric age group}

More females when compared to males said that they needed regular treatment with prescription drugs; however this association was not statistically significant. Among those needing regular treatment, females were 2.75 times more compliant when compared to males and this association was also statistically significant $(\mathrm{p}=0.002 *)$.

Details can be seen in Table 4 and the most important reason quoted for irregular treatment was the lack of company/caregiver (Figure 1).

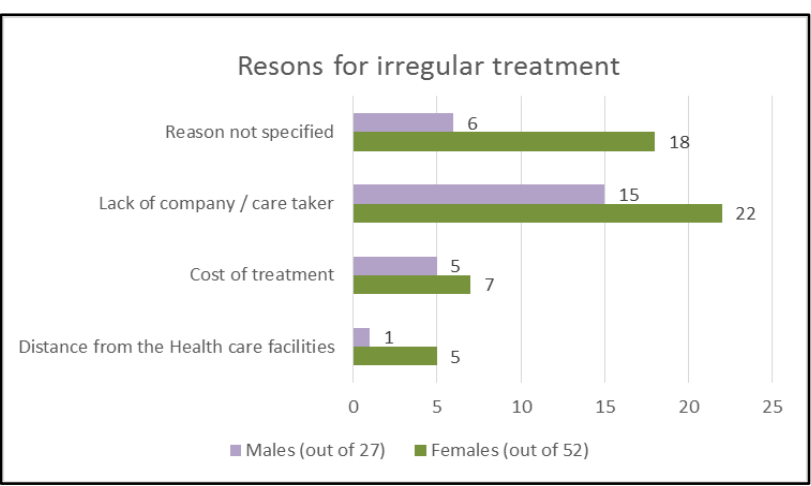

Figure 1: Reasons for irregular treatment as quoted by the geriatric subjects.

Table 3: Gender-wise distribution of certain health complaints and utilization of health services based on 3 month recall in the geriatric subjects.

\begin{tabular}{|c|c|c|c|c|}
\hline $\begin{array}{l}3 \text { month recall of certain morbidities and } \\
\text { utilization of health services }\end{array}$ & $\begin{array}{l}\text { Gender } \\
\text { (Out of } 100 \text { in } \\
\text { each group) }\end{array}$ & $\begin{array}{l}\text { Number } \\
\text { (Out of 100) }\end{array}$ & $\begin{array}{l}\text { Odd's ratio } \\
(95 \% \text { C.I })\end{array}$ & p value \\
\hline \multirow{2}{*}{ Loss of appetite } & Male & 23 & 1.00 & \multirow{2}{*}{$0.04 *$} \\
\hline & Female & 36 & $1.88(1.01-3.50)$ & \\
\hline \multirow{2}{*}{ Weight loss problems } & Male & 43 & 1.00 & \multirow{2}{*}{$0.02 *$} \\
\hline & Female & 59 & $1.91(1.09-3.35)$ & \\
\hline \multirow{2}{*}{ Mobility problems } & Male & 3 & 1.00 & \multirow{2}{*}{$0.0008 *$} \\
\hline & Female & 18 & $7.1(2.02-24.95)$ & \\
\hline \multirow{2}{*}{ Taking $>3$ prescription drugs on a regular basis } & Female & 42 & 1.00 & \multirow{2}{*}{0.20} \\
\hline & Male & 51 & $1.44(0.8-2.51)$ & \\
\hline \multirow{2}{*}{ Hospital admissions } & Male & 12 & 1.00 & \multirow{2}{*}{$0.04 *$} \\
\hline & Female & 23 & $2.19(1.02-4.69)$ & \\
\hline \multirow{2}{*}{ Ambulance services } & Male & 10 & 1.00 & \multirow{2}{*}{0.21} \\
\hline & Female & 16 & $1.71(0.74-3.99)$ & \\
\hline \multirow{2}{*}{ Specialist care } & Male & 27 & 1.00 & \multirow{2}{*}{$0.0008 *$} \\
\hline & Female & 50 & $2.7(1.5-4.88)$ & \\
\hline \multirow{2}{*}{ Private health care Facilities } & Male & 14 & 1.00 & \multirow{2}{*}{$0.02 *$} \\
\hline & Female & 28 & $2.39(1.17-4.88)$ & \\
\hline
\end{tabular}

*Statistically significant

Table 4: Gender differentials in regularity of treatment in the geriatric age group.

\begin{tabular}{|c|c|c|c|c|}
\hline Treatment patterns & Gender (Out of 100 in each group) & Number & Odd's ratio (95\% C.I.) & p value \\
\hline \multirow{2}{*}{$\begin{array}{l}\text { Number needing } \\
\text { regular treatment }\end{array}$} & Male & 77 (out of 100) & 1.00 & \multirow{2}{*}{0.07} \\
\hline & Female & 87 (out of 100) & $2.00(0.95-4.22)$ & \\
\hline \multirow{2}{*}{$\begin{array}{l}\text { Number taking regular } \\
\text { treatment }\end{array}$} & Male & 27 (out of 77) & 1.00 & \multirow{2}{*}{$0.002 *$} \\
\hline & Female & 52 (out of 87 ) & $2.75(1.46-5.19)$ & \\
\hline
\end{tabular}

*Statistically significant 


\section{DISCUSSION}

This study was a population based cross-sectional study done using stratified random sampling method, which ensures generalizability of results to the study population. The present study shows the overall rates and genderwise differences of socio-demographic profile and certain morbidities in the geriatric ( $>60$ years) people in the rural populations of Parivakkam and Kolappancheri villages and the health seeking behaviors of people with the same.

\section{Socio-demographic profile of the study subjects}

Self-earning as the main source of income was seen in $46 \%$ of the men and was more than that for women (22\%), this was comparable to the results of a survey done among rural elderly by HDIS (human development indices survey). ${ }^{9}$ In both cases financial support through self-income which is a big determinant of the level of living was considerably less among women. It was seen that the educational status was more in the males than in the females and this association was highly statistically significant $\mathrm{p}<0.000$. The study was done in the geriatric age group hence their period of education would have been three, four or in some cases more decades before when education was thought of as something that was important for males and unimportant for females which could be the reason for this difference. This was comparable with the results published by the situational analysis of elderly survey which found that only $50 \%$ of the elderly men and $20 \%$ of the rural elderly women had been literates because of formal education. ${ }^{6}$

The present study showed higher literacy than in the survey which may be because of the different ways of measuring literacy. It was seen in the present study that men had higher per-capita income than women and the association was statistically significant $(p=0.04)$. Higher per capita income would mean more financial independence and indirectly better access to health care facilities.

\section{Gender-wise differences in the utilization of health care services}

Contrary to the general assumption that women are less cared for, it was seen in the present study that utilization of health care services was better among women than men. Especially, there were statistically significant associations between the female gender and hospital admissions and the utilization of specialist care and private health care facilities in the present study. The psychosomatic component of these findings should be further researched upon. Comparison of individual variables was not possible because of lack of literature.

\section{Association between Gender and regularity of treatment in the geriatric population}

More women than men said that they needed regular treatment. However, this association was not statistically significant $(p=0.07)$. Among the number of people who said they needed regular treatment, it was seen that more women were on irregular treatment. This association was statistically significant $(\mathrm{p}=0.002)$. The commonest cause quoted for irregular treatment was lack of company/caretaker by both genders. This was different from the results seen in a study done among elderly in Shimla, in which the lack of a caretaker was quoted as the reason for taking irregular treatment by only $3.5 \%$ of the elderly.

\section{Suggestions to help overcome the gender differentials and gaps in health care services}

More focus should be given to both the physical and the social component of the elderly to improve their quality of life. A day of the week can be allotted for geriatric care in the Primary Health Centers (PHC), and the medical officer should be encouraged to make home visits with the help of a Village Health Nurse (VHN) to provide home care for those elderly who cannot visit the health care facilities due to various reasons. There is no denying the fact that women, though they live longer, suffer from a lot more morbidities than men. And it was also seen that women are more likely to be irregular with their treatment schedule. They should be motivated through psychological counseling to overcome the barriers that stop them from taking regular treatment. The government should be made aware of the economic needs of the elderly and specific job opportunities should be created to cater to their special requirements.

Funding: No funding sources

Conflict of interest: None declared

Ethical approval: The study was approved by the Institutional Ethics Committee

\section{REFERENCES}

1. Kumar AT, Sowmiya KR, Radhika G. Morbidity pattern among the elderly people living in a southern rural India: a cross-sectional study. Nat J Res Com Med. 2012;1:15-9.

2. Madhu T, Sreedevi A. A study of socio demographic profile of geriatric population in the field practice area of Kurnool Medical College. Int J Res Dev Health. 2013;1:69-76.

3. Shraddha K, Prashantha B, Prakash B. Study on morbidity pattern among elderly in urban population of Mysore, Karnataka, India. Int J Med Biomed Res. 2012;1:215-23.

4. Fee, lin and health education authority (Great Britain) assessing older people's health and social 
needs: qualitative research investigating health beliefs and social factors relevant to older people's health. London: Health Education Authority; 1999.

5. Ingle GK, Nath A. Geriatric Health in India: concerns and solutions. Indian J Comm Med. 2008;33:214-8

6. Central Statistics Office Ministry of Statistics and Programme Implementation, Government of India. Situation analysis of the elderly in India; 2011.

7. Sharma D, Mazta SR, Parashar A. Morbidity pattern and health-seeking behaviour of aged population residing in Shimla Hills of North India: a cross-sectional study. J Family Med Prim Care. 2013;2:188-93.
8. Dudala SR, Arlappa N. An updated Prasad's socio economic status classification for 2013. Int J Res Dev Health. 2013;1:26-8.

9. Gupta I, Dasgupta P, Sawhney M. Health of the elderly in India - some aspects of vulnerability. working paper, Institute of Economic Growth, Delhi; 2001.

Cite this article as: Priyanka S, Paul CMP, Dharmaraj D, Dutta KKG, Archanalakshmi PA, Paul VSV. Gender differentials in the health status of geriatric age group and their coping mechanisms. Int J Community Med Public Health 2016;3: 2716-21. 